\title{
Pembelajaran Berbicara Interaktif Bahasa Inggris di SMP
}

\author{
Risa Mufliharsi ${ }^{1}$, Eva Nurul Candra ${ }^{2}$ \\ ${ }^{1,2}$ Universitas Indraprasta PGRI Jakarta \\ 1risa.mufliharsi@unindra.ac.id, ${ }^{2}$ evanurulcandra@yahoo.com
}

\begin{abstract}
The purpose of this community service for increasing teachers' competence in Junior High School teachers especially English teacher in learning interactive speaking. The output is journal which contains the implementation of speaking activities that is suitable for Junior High School grades. Besides, there is a booklet for teachers in teaching speaking and also can be implemented in English club as extracuricular. The activities are 1) doing presentation and explaining clearly related to how to do interactive speaking through many techniques and methods. 2) Doing presentation and explaining related to indicators needed. 3) guiding and accompanying Junior High School teachers in practice and simulating. 4) doing interactive discussion about the workshop.
\end{abstract}

Keywords : Learning, interactive speaking, English subject

\begin{abstract}
ABSTRAK
Tujuan yang dicapai pada kegiatan ini adalah meningkatkan kompetensi para guru sekolah menengah pertama terutama pembelajaran berbicara bahasa Inggris secara interaktif dan transaksional. Luaran yang akan dihasilkan adalah berupa jurnal berisikan penerapan berbagai pembelajaran berbicara yang disesuaikan untuk sekolah menegah pertama. Selain itu, juga booklet untuk para guru dalam mengajarkan berbicara bahasa Inggris yang bisa diterapkan di kelas ataupun ekstrakurikuler English Club di SMPIT Yayasan Tunas Harapan Ilahi dan SMP Negeri 9 Bekasi. Kegiatan yang dilakukan antara lain: 1) Melakukan presentasi dan memberikan penjelasan mengenai bagaimana pembelajaran berbicara interaktif melalui berbagai teknik maupun metode pembelajaran, 2) Melakukan presentasi dan memberikan penjelasan mengenai klasifikasi capaian aspek yang ditekankan, 3) Membimbing dan mendampingi para guru SMPIT Tunas Harapan Ilahi dan SMP Negeri 9 Bekasi dalam melakukan praktek atau simulasi sederhana dalam sosialisasi tersebut. 4) Melakukan sesi tanya jawab mengenai pelatihan yang tergambar dari awal hingga akhir
\end{abstract}

Kata kunci : Pembelajaran, Berbicara interaktif, mata pelajaran bahasa Inggris

\section{PENDAHULUAN}

Berbicara dalam bahasa asing, salah satunya bahasa Inggris, diperlukan perhatian yang khusus. Sebagai pendidik, perlu meninjau berbagai aspek terlebih dahulu agar pencapaian pembelajaran bahasa Inggrisnya terpenuhi, salah satunya dengan menggunakan metode pembelajaran yang disesuaikan dengan tujuan pembelajaran yang ingin dicapai. Terkait dengan tujuan, berbicara dibagi menjadi beberapa tipe menurut Brown (2001) disesuaikan dengan penilaian berbicara antara lain:1. imitative speaking; 2. intensive speaking; 3. responsive speaking; 4.interactive speaking; 5. extensive speaking. Berbicara imitatif memfokuskan pada peniruan berbicara; berbicara intensif memfokuskan pada kemampuan berbahasa pada tingkatan tertentu, umumnya pada tata bahasa, kosakata, ataupun kemampuan bahasa yang lain; berbicara resposif memfokuskan pada keterampilan siswa merespon ungkapan yang sebelumnya disimak oleh para siswa; berbicara interaktif memfokuskan pada interaksi dan transaksi yang terjadi pada wacana monolog dan fungsional; dan berbicara ekstensif memfokuskan pada keterampilan melibatkan baik kompetensi pengembangan wacana monolog atau fungsional pada wacana yang lebih panjang dan menunjukkan keterampilan dan kemampuan yang lebih tinggi.

Pengenalan wacana interaktif dan transaksional sejak dini sudah dimasukkan dalam pembelajaran bahasa Inggris dimulai di jenjang Sekolah Menengah Pertama. Pada kurikulum KTSP baik 2006 ataupun 2010, wacana interaktif sudah dimasukkan dalam standar isi yang selanjutnya dikembangkan melalui silabus lalu rencana pelaksanaan pembelajaran di kelas. Idealnya, wacana interaktif akan tercapai apabila wacana tersebut diajarkan pula dengan metode pembelajaran yang bertujuan menjadikan teks yang diajarkan menjadi interaktif dan transaksional. 
Metode pembelajaran pada pembelajaran interaktif antara lain yang memfokuskan pada pembangunan interaksi yang dilakukan oleh para siswa sehingga para siswa dapat menggunakan wacana tersebut pada kegiatan ataupun peristiwa yang bisa temui dalam kehidupan sehari hari. Metode pembelajaran yang umumnya dipakai antara lain: Communicative Language Teaching, Cooperative Language Learning, CLIL, Whole language, Competency-Based Language Teaching, Task-Based Language Teaching, Text-Based Instruction, The Lexical Approach dan Multiple Intellegence.

Pada pembelajaran berbicara interaktif, fokus pembelajaran pada interaksi dan transaksi yang terjalin antara pembicara dan lawan bicara sehingga terbentuk wacana yang nantinya bisa dipakai pada kehidupan sehari hari. Unsur ini penting, karena tujuan berbicara pada aspek ini adalah sebagai sarana berkomunikasi untuk mengungkapkan ide, gagasan, dam pendapat antar penutur. Namun, kenyataannya pembelajaran di kelas kadang tidak sesuai dengan tujuan pembelajaran yang didesain. Masih ditemui di lapangan, terutama pada pembelajaran berbicara di tingkat pertama pembelajaran hanya fokus pada berbicara imitatif, intensif, dan responsif. Pada pembelajaran berbicara ini, tentunya peran guru sangat dominan berperan pada keseluruhan materikegiatan pembelajaran di kelas.

Oleh karena itu, tim abdimas mensosialisasikan Interactive Speaking Class pada para guru bahasa Inggris di tingkat sekolah menengah pertama, yakni di SMPIT Tunas Harapan Ilahi dan SMP Negeri 34 Bekasi. Pada sosialisasi ini, tim memfokuskan pada teknik teknik pembelajaran yang nantinya dapat diterapkan oleh para guru baik saat pembelajaran di kelas pada mata pelajaran bahasa Inggris dan juga pada ekstrakurikuler yang berkaitan dengan bahasa Inggris, yakni English $C l u b$. Diharapkan, dengan pembiasaan memperoleh bahasa Inggris baik di dalam kelas ataupun di luar kelas dapat meningkatkan keterampilan berbicara para siswa.

Adapun permasalahan yang muncul antara lain:

1) Sekolah SMP maupun SMPIT belum membiasakan penggunakan bahasa Inggris sebagai pengantar bagi guru dan siswa di lingkungan sekolah di luar pelajaran Bahasa Inggris secara lisan.

2) Belum adanya English Club di SMP ataupun SMPIT sebagai ekstrakurikuler.

Tim fokus memberikan sosialisasi kepada guru guru bahasa Inggris di SMP Negeri 34 Bekasi maupun SMPIT Tunas Harapan Ilahi dikarenakan masih kurangnya keterampilan berbicara bahasa Inggris para siswa di lingkungan sekolah. Padahal sarana dari sekolah yakni SMP Negeri 34 maupun SMPIT Tunas Harapan Ilahi dirasa cukup memadai. Disini, tim berasumsi belum dibiasakannya para siswa menggunakan bahasa Inggris di area sekolah baik antar siswa maupun siswa dengan guru.

Karakteristik berbicara dijabarkan oleh Bailey, Berbicara merupakan keterampilan secara langsung ataupun lisan yang berisikan ujaran ujaran verbal sistematis secara produktif untuk menyampaikan makna secara langsung dan dapat dipahami. (Nunan : 2003).

Terdapat berbagai alasan seseorang untuk berbicara, antara lain: memproduksi ujaran, keaslian dari tujuan berkomunikasi, mengekpresikan ide dan opini secara langsung dan memunculkan ekspresi secara alami. (McDonough dan Shaw: 2005). Oleh karena itu, sangat perlu bagi para guru untuk mengajarkan berbicara sejak dini untuk membiasakan para siswa untuk menyampaikan ide,gagasan, pikiran dan ekspresi yang sesuai dengan konteks lisan yang sebenarnya, sehingga tujuan berkomunikasi dapat terpenuhi.

Maka, perlu adanya buku panduan untuk para guru untuk mengajar berbicara kepada para siswa di sekolah. Di sini, tim memberikan sosialisasi teknik pada keterampilan berbicara yang disesuaikan dengan tingkat siswa. Tim memberikan booklet yang berjudul Easy Steps to Teach Interactive Speaking. Diharapkan, booklet ini dapat berguna bagi para guru bahasa Inggris di SMPIT Tunas Harapan Ilahi dan SMP Negeri 34 Bekasi.

\section{METODE PELAKSANAAN}

\section{Sasaran Kegiatan}

Sasaran kegiatan pengabdian masyarakat ini adalah para guru bahasa Inggris SMPIT Yayasan Tunas Harapan Ilahi, Cipondoh dan SMP Negeri 34 Bekasi. 


\section{Materi dan Pelaksanaan Kegiatan}

Materi yang digunakan dalamkegiatan ini adalahpengajaran berbicara bahasa Inggris bagi para guru bahasa Inggris di SMPIT Yayasan Tunas Harapan Ilahi, Cipondoh dan SMP Negeri 34 Bekasi. Nantinya, pengajaran berbicara interaktif tersebut akan diajarkan kepada para siswa SMPIT Yayasan Tunas Harapan Ilahi dan SMP Negeri 34 Bekasi pada pembelajaran di kelas ataupun di program ekstrakurikuler English Club. Tentunya, pembelajaran bahasa Inggris di dalam kelas masih belum cukup. Oleh karena itu, diperlukan pula pembelajaran di luar kelas sehingga pembelajaran bahasa Inggris menjadi lebih menarik dan interaktif.

Beberapa prosedur pelaksanaan yang dilakukan dalam kegiatan ini adalah sebagai berikut:

a. Melakukan presentasi dan memberikan penjelasan mengenai bagaimana pembelajaran berbicara interaktif melalui berbagai teknik maupun metode pembelajaran.

b. Melakukan presentasi dan memberikan penjelasan mengenai klasifikasi capaian aspek yang ditekankan.

c. Membimbing dan mendampingi para guru SMPIT Tunas Harapan Ilahidan SMP Negeri 34 Bekasi dalam melakukan praktek atau simulasi sederhana dalam sosialisasi tersebut.

d. Melakukan sesi tanya jawab mengenai pelatihan yang tergambar dari awal hingga akhir

\section{Pelaksanaan Kegiatan}

Berikut adalah susunan acara sosialisasi genre-based approach of daily school's interaction in speaking context di SDIT dan SMPIT Tunas Harapan Ilahi Cipondoh - Kota Tangerang.

Langkah langkah prosedur kerja yang akan dilakukan antara lain:

\section{Sosialisasi di SMPIT THI :}

\section{Pertemuan Pertama}

a. Kelompok abdimas menjelaskan teori dan konsep TEFL.

b. Kelompok abdimas menjelaskan teori dan konsep pembelajaran bahasa Inggris dan tujuannya.

c. Kelompok abdimas menjelaskan langkah-langkah penerapan pembelajaran berbicara interaktif Bahasa Inggris.

d. Kelompok abdimas memberikan contoh penerapan metode CLL kepada peserta sosialisasi.

e. Peserta sosialisasi mempraktekkan penggunaan metode CLL dengan sesama peserta.

2. Pertemuan kedua

a. Kelompok abdimas melakukan pengamatan di tempat mitra mengenai hasil dari sosialisasi penggunaan metode CLL.

b. Kelompok abdimas melakukan sesi tanya jawab dengan para guru yang telah mengikuti sosialisasi metode pengajaran CLL.

c. Kelompok abdimas melakukan sesi sharing mengenai kendala-kendala penerapan CLL bersama para guru.

d. Sosialisasi selesai.

\section{Sosialisasi di SMPN 34 Bekasi :}

\section{Pertemuan Pertama}

a. Kelompok abdimas menjelaskan teori dan konsep TEFL.

b. Kelompok abdimas menjelaskan teori dan konsep pembelajaran bahasa Inggris dan tujuannya.

c. Kelompok abdimas menjelaskan langkah-langkah penerapan pembelajaran berbicara interaktif Bahasa Inggris.

d. Kelompok abdimas memberikan contoh penerapan metode CLL kepada peserta sosialisasi.

e. Peserta sosialisasi mempraktekkan penggunaan metode CLL dengan sesama peserta.

2. Pertemuan kedua

a. Kelompok abdimas melakukan pengamatan di tempat mitra mengenai hasil dari sosialisasi penggunaan metode CLL.

b. Kelompok abdimas melakukan sesi tanya jawab dengan para guru yang telah mengikuti sosialisasi metode pengajaran CLL. 
c. Kelompok abdimas melakukan sesi sharing mengenai kendala-kendala penerapan CLL bersama para guru.

d. Sosialisasi selesai.

Tabel 1. Susunan acara kegiatan sosialisasi di SMPIT THI

\begin{tabular}{|c|c|c|c|c|}
\hline No & Waktu & Hari/tanggal & Acara & Keterangan \\
\hline 1 & $08.00-08.30$ & Sabtu, 14 April 2018 & Pembukaan & $\begin{array}{l}\text { Humas yayasan Tunas } \\
\text { Harapan Ilahi }\end{array}$ \\
\hline 2 & $08.30-09.00$ & Sabtu, 14 April 2018 & $\begin{array}{l}\text { Menyanyikan lagu } \\
\text { kebangsaan Indonesia } \\
\text { Raya }\end{array}$ & $\begin{array}{l}\text { Eva Nurul Candra, } \\
\text { S.S, M.Pd }\end{array}$ \\
\hline 3 & $09.00-09.15$ & Sabtu, 14 April 2018 & $\begin{array}{l}\text { Sambutan oleh Kepala } \\
\text { Sekolah SDIT THI }\end{array}$ & Ayom Djatmiko, S.Pd \\
\hline 4 & $09.15-09.30$ & Sabtu, 14 April 2018 & $\begin{array}{l}\text { Sambutan oleh ketua } \\
\text { abdimas }\end{array}$ & $\begin{array}{l}\text { Eva Nurul Candra, } \\
\text { S.S, M.Pd }\end{array}$ \\
\hline 5 & $09.30-10.00$ & Sabtu, 14 April 2018 & $\begin{array}{l}\text { Sosialisasi sesi I: } \\
\text { Presentasi mengenai teori } \\
\text { dan konsep pembelajaran } \\
\text { bahasa Inggris dan } \\
\text { tujuannya }\end{array}$ & Risa Mufliharsi, M.Pd \\
\hline 6 & $10.00-10.30$ & Sabtu, 14 April 2018 & $\begin{array}{l}\text { Presentasi } \\
\text { mengenaimenjelaskan } \\
\text { TEFL }\end{array}$ & Risa Mufliharsi, M.Pd \\
\hline 7 & $10.30-12.00$ & Sabtu, 14 April 2018 & $\begin{array}{l}\text { Presentasi mengenai } \\
\text { metode pembelajaran } \\
\text { CLL }\end{array}$ & Tim abdimas \\
\hline 8 & & & ISHOMA & \\
\hline 9 & $13.30-14.00$ & Sabtu, 14 April 2018 & $\begin{array}{l}\text { Praktek penerapan metode } \\
\text { CLL oleh para guru }\end{array}$ & $\begin{array}{l}\text { Eva Nurul Candra } \\
\text { S.S., M.Pd }\end{array}$ \\
\hline 10 & $14.00-15.00$ & Sabtu, 14 April 2018 & Q n A & $\begin{array}{l}\text { Tim abdimas dan Para } \\
\text { Guru }\end{array}$ \\
\hline $\begin{array}{l}11 \\
12\end{array}$ & $\begin{array}{l}15.00-16.30 \\
17: 00\end{array}$ & Sabtu, 14 April 2018 & $\begin{array}{l}\text { Review materi sosialisasi } \\
\text { PENUTUPAN }\end{array}$ & Tim abdimas \\
\hline
\end{tabular}

Tabel 2. Susunan acara kegiatan sosialisasi di SMPN 34 Bekasi

\begin{tabular}{|c|c|c|c|c|}
\hline No & Waktu & Hari/tanggal & Acara & Keterangan \\
\hline 1 & $08.00-08.30$ & Sabtu, 12 Mei 2018 & Pembukaan & $\begin{array}{l}\text { Wakil Kepala Sekolah } \\
\text { SMPN } 34\end{array}$ \\
\hline 3 & $09.00-09.15$ & Sabtu, 12 Mei 2018 & $\begin{array}{l}\text { Sambutan oleh Kepala } \\
\text { Sekolah SMPN } 34\end{array}$ & $\begin{array}{l}\text { Dra. Hj. Anita Leni., } \\
\text { M.Pd. }\end{array}$ \\
\hline 4 & $09.15-09.30$ & Sabtu, 12 Mei 2018 & $\begin{array}{l}\text { Sambutan oleh ketua } \\
\text { abdimas }\end{array}$ & $\begin{array}{l}\text { Eva Nurul Candra, S.S, } \\
\text { M.Pd }\end{array}$ \\
\hline 5 & $09.30-10.00$ & Sabtu, 12 Mei 2018 & $\begin{array}{l}\text { Sosialisasi sesi I: } \\
\text { Presentasi mengenai teori } \\
\text { dan konsep pembelajaran } \\
\text { bahasa Inggris dan } \\
\text { tujuannya }\end{array}$ & Risa Mufliharsi, M.Pd \\
\hline 6 & $10.00-10.30$ & Sabtu, 12 Mei 2018 & $\begin{array}{l}\text { Presentasi } \\
\text { mengenaimenjelaskan } \\
\text { TEFL }\end{array}$ & Risa Mufliharsi, M.Pd \\
\hline 7 & $10.30-12.00$ & Sabtu, 12 Mei 2018 & $\begin{array}{l}\text { Presentasi mengenai } \\
\text { metode pembelajaran } \\
\text { CLL }\end{array}$ & Tim abdimas \\
\hline
\end{tabular}




\begin{tabular}{lccll}
\hline No & Waktu & \multicolumn{1}{c}{ Hari/tanggal } & \multicolumn{1}{c}{ Acara } & \multicolumn{1}{c}{ Keterangan } \\
\hline 8 & & & ISHOMA & \\
9 & $13.30-14.00$ & Sabtu, 12 Mei 2018 & $\begin{array}{l}\text { Praktek penerapan } \\
\text { metode CLL oleh para } \\
\text { guru }\end{array}$ & $\begin{array}{l}\text { Eva Nurul Candra } \\
\text { S.S., M.Pd }\end{array}$ \\
& & Q n A & $\begin{array}{l}\text { Tim abdimas dan Para } \\
\text { Guru }\end{array}$ \\
10 & $14.00-15.00$ & Sabtu, 12 Mei 2018 & Review materi sosialisasi & Tim abdimas \\
11 & $15.00-16.30$ & Sabtu, 12 Mei 2018 & RENUTUPAN & \\
12 & $17: 00$ & & &
\end{tabular}
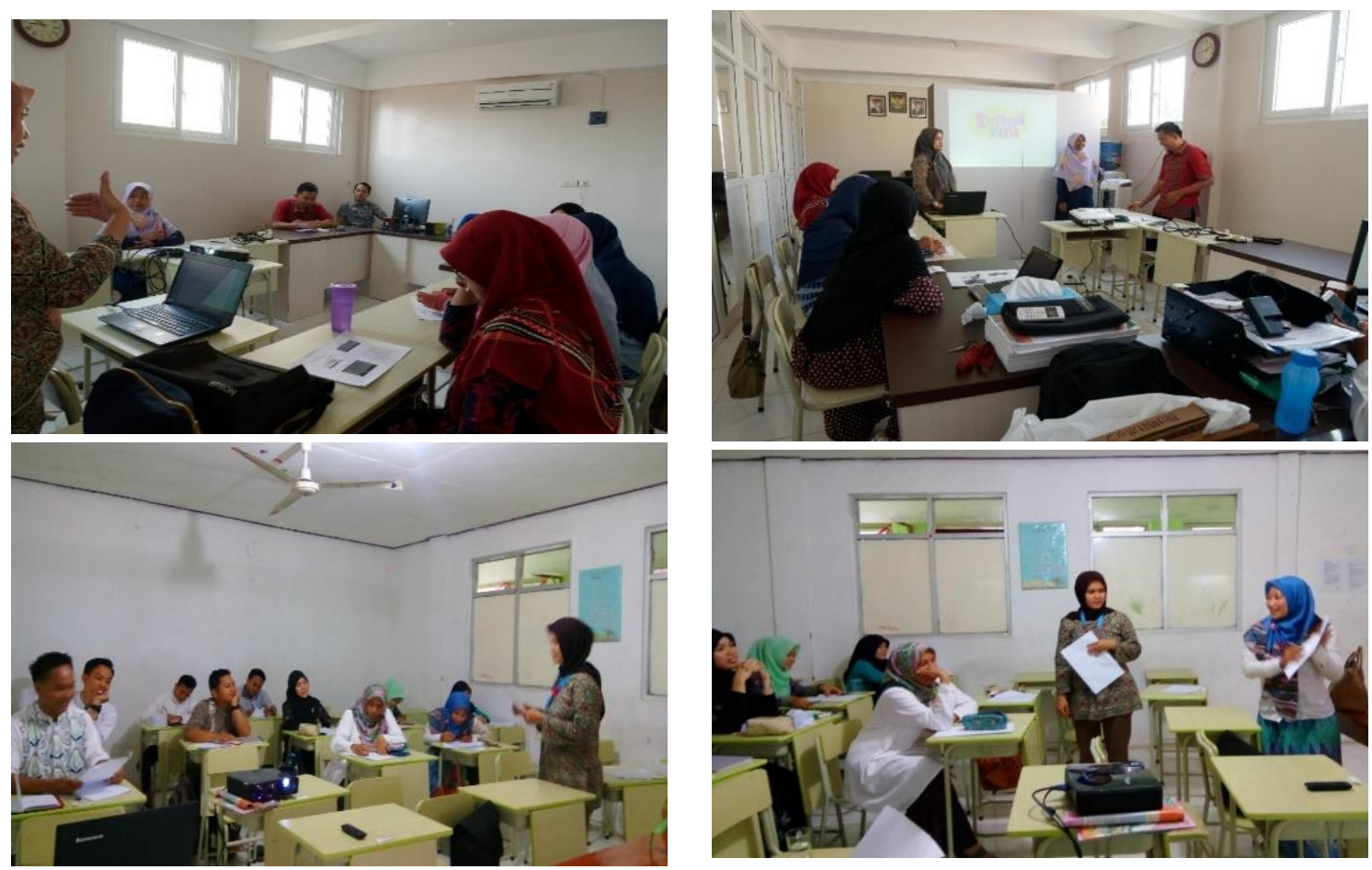

Gambar 1. Tim abdimas sedang memberikan penjelasan mengenai sosialisasi pembelajaran berbicara interaktif Bahasa Inggris di SMPIT THI dan SMP 34 Bekasi

Tabel 3. Susunan Tim pengabdian masyarakat yang berjudul "Sosialisasi Pembelajaran Berbicara Interaktif Bahasa Inggris di SMP"

\begin{tabular}{lll}
\hline No & \multicolumn{1}{c}{ Nama } & \multicolumn{1}{c}{ Penjelasan } \\
\hline 1 & Eva Nurul Candra, S.S., M.Pd & $\begin{array}{l}\text { Dosen Pengampu Mata Kuliah Reading } \\
\text { Comprehension and Writing } \\
\text { Dosen Pengampu Mata Kuliah Language } \\
\text { testingdan PPBI }\end{array}$ \\
\hline
\end{tabular}

\section{HASIL DAN PEMBAHASAN}

Kegiatan Pengabdian Pada Masyarakat ini dilaksanakan dalam bentuk sosialisasi, seperti yang ditunjukkan pada tabel berikut. 
Tabel 4. Rincian Kegiatan

\begin{tabular}{ll}
\hline Pertemuan & \multicolumn{1}{c}{ Rincian Kegiatan } \\
\hline \multirow{3}{*}{1} & Sosialisasi program \\
\cline { 2 - 2 } & $\begin{array}{l}\text { Materi, diskusi dan tanya jawab seputar pembelajaran bahasa } \\
\text { Inggris dan media pendukung pembelajaran bahasa Inggris. }\end{array}$ \\
\cline { 2 - 2 } & $\begin{array}{l}\text { Penggalian konsep-konsep tentang media pembelajaran bahasa } \\
\text { Inggris yang kreatif dan inovatif. }\end{array}$ \\
\cline { 2 - 2 } & $\begin{array}{l}\text { Penjelasan pembelajaran interaktif Bahasa Inggris yang } \\
\text { dibimbing langsung oleh pemateri. }\end{array}$ \\
\cline { 2 - 2 } & Praktek penggunaan media \\
\cline { 2 - 2 } & Evaluasi program yang dilakukan di akhir kegiatan \\
\hline
\end{tabular}

\section{Luaran}

Luaran yang akan dihasilkan adalah berupa jurnal berisikan penerapan pembelajaran interaktif Bahasa Inggris pada interaksi keseharian di sekolah pada konteks berbicara. Yang nantinya akan ditindaklanjuti untuk membuat membuat media media yang menarik sehingga bisa diterapkan di sekolah. Media yang akan dihasilkan adalah booklet daily conversation pocket book untuk para siswa.

\section{KESIMPULAN}

Sesuai dengan hasil yang diperoleh oleh tim, maka dapat disimpulkan bahwa :

1. Pelatihan berbicara secara interaktif terbukti membantu meningkatkan keterampilan berbicara siswa SMP, dengan begitu perlu adanya English club untuk memfasilitasi siswa dalam meningkatkan keterampilan berbicara bahasa Inggris.

2. Para guru dapat menggunakan daily conversation book sebagai materi penunjang pada pembelajaran yang akan diterapkan di English Club ini..

\section{DAFTAR PUSTAKA}

McDonough, Jo and Christoper Shaw (2005). Materials and Methods in ELT. United Kingdom: Blackwell Publishing

Nunan, David (2003). Practical English Language Teaching. United States: Mc Graw Hill.

Prawiradilaga, Dewi Salma. (2007). Prinsip Disain Pembelajaran. Jakarta: Kencana, Universitas Negeri Jakarta.

Brown, H. Douglas.(2001). Teaching by Principles An Interactive Approach to Language Pedagogy: Second Edition. New York: Longman.

https://smpit.thi.or.id/ diakses pada 15 Agustus 2017 pukul 13.20 